\title{
TRES NOCIÓNS DE PLURALISMO NO ESPAZO PÚBLICO
}

Carlos Thiebaut

Universidad Carlos III de Madrid 



\section{DUNHA DIFICULTADE -NOSA- PARA VER E PENSAR O PLURALISMO}

Hai realidades difíciles de pensar para algunhas culturas políticas. Pensar o tema do pluralismo é significativamente difícil naquelas culturas, coma as latinoamericanas e ibéricas, que son herdeiras do que se podería chamar o comunitarismo de Estado, un sistema de formas políticas, culturais e ideolóxicas que se constrúen en maneiras fortemente homoxéneas de entender a comunidade social e política. O comunitarismo de Estado, herdeiro no político de formas absolutistas de configuración do poder e no ideolóxico e o relixioso da Contrarreforma, fixo invisibles as diferenzas culturais, as existentes ou as emerxentes, e expulsounas -por medio da represión e mais da asfixia- ao reino da inexistencia pública. Procedemos dunha dolorosa cultura en que os individuos, as persoas, non podían arriscarse a mostrar discrepancias e que está marcada por unha longa senda de marxinación e de resistencia, de silencio e represión, de exilio e encarceramentos, que é a marca negra que non debemos esquecer. A ontoloxía política do comunitarismo de Estado -por diversas que fosen as súas formas nas colonias e nas metrópoles- concibe os seus entes, sexan os individuos ou os grupos, como dependentes e subordinados a un grande ente ou un gran Ser fóra do que, en termos relixiosos, non existe salvación e á marxe do que, en termos institucionais, non cabe a existencia política. E, de xeito máis significativo, eses entes non poden concibir nin a súa propia existencia nin o seu significado fóra da dependencia do Estado ou da relixión ou de calquera das súas felices coimplicacións estruturais. Durante toda a Idade Moderna, os triunfais programas imperialistas ibéricos atoparon un inesperado aliado para a ontoloxía do seu comunitarismo político nas formas comunais de organización das culturas indíxenas e cando non o acharon tiveron que impoñelo. A consecuencia relevante para o que tratamos é a invisibilidade ou a inexistencia do pluralismo; 
pero, sobre todo, a dificultade para pensalo na medida en que sigamos a operar no marco da devandita ontoloxía política.

A necesidade de cambiar esa ontoloxía política para pensar a realidade foise facendo progresivamente máis axexante nas últimas décadas, cando se fixo visible unha diversidade non visible ata entón -como acontece coa das culturas que foron marxinadas nos procesos de homoxeneización- ou cando emerxeron novas formas de diversidade de estilos de vida, mesmo alí onde a homoxeneidade comunitarista fora hexemónica. A pluralización das formas de vida, co pluralismo ético, de valores e de prácticas, coa crecente presenza de interpretacións que, procedentes de posicións distintas no tecido social, reclaman a súa visibilidade e a súa relevancia pública, requiren superar as dificultades de comprensión que impón o comunitarismo de Estado e a interpretación do mundo público coma un espazo homoxéneo e falsamente - pensamos agora- igualitario. Lembremos o caso tan relevante da mirada, da acción e da realidade femininas. Volver pensar na unión social tras o recoñecemento da existencia das culturas indíxenas, da asimétrica realidade das posicións sociais e das novas formas de construcións das identidades -nas que o comunitarismo homoxéneo de Estado se difractou de múltiples maneiras, quizais, non obstante, sen desaparecer totalmente- semella requirirnos o cambio en que estou a chamar a comprensión da nosa ontoloxía política. O que querería soster, de entrada, é que a nosa percepción ou o noso concepto do pluralismo é determinante para comprender o espazo público e esa unidade de axencia que denominaba, con Rawls, a «unión Social» ${ }^{1}$-ou a unión social das «unións sociais», por ser máis fiel ao seu concepto.

\section{A PERCEPCIÓN DO PLURALISMO AFECTA A NOSA NOCIÓN DO ESPAZO PÚBLICO}

A hipótese central que guiará a miña reflexión é que concibiremos como é e como debe ser o espazo público segundo sexan as nosas concepcións de que é o que fai diferentes as persoas e que, así mesmo, distintas concepcións desa diversidade supoñen distintas nocións de como é o espazo público e de cal debería ser o seu

${ }^{1} \mathrm{O}$ concepto de «unión social» procede de Wilhelm von Humboldt (1993, p. 11). 
rol e a súa estrutura e de como habería de estar regulado. Sen pretensión exhaustiva describirei tres tipos ideais de comprensións desa diversidade que serán, segundo a hipótese, tamén formas de comprender o espazo público. A primeira delas, que parte da tradición que inaugura Humboldt e que desenvolve Mill, concibe o pluralismo como a constatación das diferenzas das persoas cuxas capacidades se desenvolven de maneira específica, diversa; a protección deste desenvolvemento é a razón normativa que debe rexer as actuacións públicas. Suxerirei que esta forma de protoliberalismo, que poderiamos chamar orgánico, non aparece só no momento histórico do Romanticismo, primeiro ou tardío, senón que está presente hoxe en propostas como o enfoque das capacidades de Amartya Sen. A segunda forma de concepción do pluralismo cambia o foco de atención cara á perspectiva dos individuos en canto participantes no espazo público e pode adquirir diversas tonalidades en filosofías que aparecen, mesmo, afastadas. A súa intuición é que os individuos, as persoas, son entidades irredutibles nas súas diferenzas e insubstituíbles á hora de definir a lexitimidade dunha norma segundo a que eses diferentes suxeitos haberían de comportarse. A diferenza das persoas que Arendt acentúa ao falar da política, a abismal infinidade das relacións de encontro co outro -a súa irredutibilidade- en Levinas ou a imposibilidade de substituír dos afectados nos discursos prácticos na proposta discursiva de Habermas apuntan a esta intuición que semella recoller, de maneiras diversas, a idea kantiana das persoas como «fins en si mesmos» e, neste caso, como interpelantes últimos ou fontes últimas da lexitimación das normas que lle darán corpo á unión social. Finalmente, e en terceiro lugar, cabe pensar no pluralismo coma unha inevitable condición que lles afecta ás interaccións e ás ordes sociais na medida en que as "posicións epistémicas» dos individuos -pero tamén dos grupos sociais- están determinadas polas súas respectivas posicións na armazón da sociedade e diante da realidade social e natural. Obviamente, o liberalismo rawlsiano é o que mellor exemplifica actualmente, coa súa teoría das cargas do xuízo, esta concepción pluralista do que non pode erradicarse nas sociedades complexas: as diferenzas razoables, na terminoloxía de Rawls, que proceden de posicións epistémicas irredutibles, non sendo por medio dun exercicio da violencia, como o do comunitarismo de Estado do que antes falamos. O pluralismo orgánico, o pluralismo da «insubstituibilidade» pública e o pluralismo epistémico son tres ideas abstractas que apuntan a tres 
tipos ideais de ontoloxía. Pero, no seu desenvolvemento en cadansúas doutrinas ou reflexións filosóficas, con frecuencia solápanse. Mill, por exemplo, argumenta a súa firme defensa do individualismo sobre argumentos epistémicos e Habermas, pola súa parte, concibe a irredutibilidade ou a imposibilidade de substituír as persoas en discursos prácticos por un xiro epistémico da súa noción da xustificación das normas. Levinas introduce na súa noción de vontade un elan que se solapa coa enerxía creativa de Humboldt. Rawls, por último, conxuga en non poucos momentos a súa reflexión sobre as cargas do xuízo e sobre o poder moral do que é razoable cunha reflexión, tomada de Humboldt, que bebe da idea dun sistema social que se organiza na riqueza dunha diversidade complementaria de desenvolvementos diversos dos plans de vida dos individuos.

Non obstante, e para efectos analíticos, cabe pensar que esas tres concepcións apuntan a tres formas distintas de entender o pluralismo nas sociedades contemporáneas, formas que, decote, se presentan na vida pública e no debate ideolóxico nun antagonismo que as fai irredutibles entre si, arrebolando -novamente, segundo as hipóteses- tres concepcións contrastadas do público. Na última parte da miña intervención suxerirei brevemente a necesidade dunha reconstrución desas tres concepcións que precisamos para articular teoricamente as tres intuicións subxacentes nos tres paradigmas enfrontados.

\section{A ONTOLOXÍA POLÍTICA DO PLURALISMO ORGÁNICO}

Nun pequeno traballo que foi publicado postumamente, pero que tivo unha grande influencia no pensamento político posromántico, Wilhelm von Humboldt estableceu a idea central que articularía unha significativa versión do pensamento liberal. En Ideas para un ensaio que determina os limites da actividade do Estado (1993, p. 33) formula un principio de abstención política que reza que «o Estado ha de absterse de calquera solicitude cara ao benestar positivo dos cidadáns e non ha de dar un paso alén do necesario para a súa seguridade mutua e para a protección diante dos inimigos externos; pois con ningún outro obxecto pode impor restricións sobre a liberdade». Máis que as razóns políticas das teses de Humboldt, que teñen que ver, sobre todo, coa súa oposición á forma absolutista de Estado e cun programa xeral de reforma ilustrada, interesa agora 
ter en conta as razóns filosóficas que radican no concepto de liberdade subxacente e no significado que esta haberá de ter. O público -neste caso, o Estado- ten só un rol protector desa liberdade. Cunha linguaxe que lembra o último Kant, Humboldt (1993 p. 10) postula que o «verdadeiro obxectivo do home, ou o que lle ditan os eternos e inmutables mandatos da razón, e que non lle vén suxerido por vagos e mutables desexos, é o do desenvolvemento superior e máis harmonioso das súas capacidades ata acadar un todo completo e coherente. A liberdade é a condición primeira e indispensable que este desenvolvemento presupón; pero [e a cautela é crucial para as nosas consideracións] existe unha variedade de situacións». Este paso, que será citado por Mill en Sobre a liberdade, fai aterrar o imperativo, asemade moral e natural, do pleno desenvolvemento humano sobre as formas sociais e políticas e da existencia: o mandato da razón, a liberdade, aterra sobre a natureza, sobre a primeira e a segunda natureza. A inferencia que diso se deducirá, e de cuxa importancia fará repetidamente eco Rawls nos nosos días, é que a liberdade e a variedade de circunstancias do seu exercicio -algo que en espírito kantiano vai alén de Kant- fai que o desenvolvemento en cada ser humano dese mandato da liberdade sexa exercido de maneira diversa e parcial, na particularidade circunstanciada de cada individuo. Cada un deberá «combinar harmonicamente» o seu pasado e o seu proxecto e prestarlle unidade á multiplicidade de obxectos da súa busca e da súa formación. E, igual que existe unha unicidade orixinaria que harmonicamente combina o proxecto de formación e de desenvolvemento de cada un, tamén, nunha orde xa distinta, «a unión social [...], baseada nas necesidades internas e as capacidades dos seus membros, [posibilita] que cada un poida participar nos ricos recursos colectivos de todos os demais» (Von Humboldt, 1993, p. 11). Esta concepción, positiva e case republicana, da orde social -unha copia do «reino dos fins en si» kantianossemella apuntar ao desenvolvemento, fundador e orixinario, dunha orde de natureza racional; é ese desenvolvemento -que antes denominei orgánico- de orde interna á natureza o que xustificará a restrición da acción política externa, do Estado, sobre esa unión social de orde moral ou racional. Resulta interesante esta reticencia do primeiro liberalismo a equiparar as razóns filosóficas da liberdade coas razóns políticas que poden deseñar o seu exercicio. A ontoloxía orgánica da liberdade orixinaria, que naturalmente se ordenará na unión social, é a razón que xustifica que a forma política desta orde teña que respectar a súa 
dinámica e a súa forza. $\mathrm{O}$ político está subordinado ao moral e natural. Todo o traballo de Humboldt está dedicado, podemos dicir de maneira antihegeliana, a indicar que a reflexión política só se pode desenvolver cando respecta o mandato superior e anterior dese desenvolvemento único e orixinario da liberdade de cada un e se axusta á confianza na harmonía natural que se dá no individuo e na especie na súa unión social. As institucións do Dereito, civil e penal, as das administracións política e militar, a separación radical da Igrexa e mais do Estado, e mesmo as políticas de seguridade -que han de prohibir aquelas políticas que impliquen a restrición dos dereitos dos cidadáns- son todas formas de protección que se xustifican na confianza de base posta no desenvolvemento orgánico e moral da liberdade do individuo.

Esta forma de ontoloxía política perde a súa, digamos, xermana confianza na filosofía da natural historia humana na reflexión vitoriana que inmediatamente herda o seu impulso liberal. John Stuart Mill, en Sobre a liberdade, un texto que mostra a clara pegada humboldtiana, reterá normativamente esa confianza de base sen, non obstante, subscribir - polo menos tan claramente como Humboldt- a confianza na unión social ou entendéndoa fóra do organicismo en que foi orixinalmente formulada. Pero hai tamén unha particularidade de base que paga a pena resaltar porque lembra o punto do que partía nesta intervención: a, ás veces irritada, sempre apaixonada, crítica ás formas de sometemento aos costumes e ás ideoloxías dominantes que, pensa Mill, producen as tiranías -en concreto, a tiranía da maioría, que opera sobre todo por medio das formas políticas da autoridade social. O principio do libre desenvolvemento de cada un, que se ve frustrado por esas formas de tiranía, ten en Mill unha xustificación algo diferente da que vimos en Humboldt, pero no seu mesmo espírito. Di nese traballo (1980, p. 123): «Aquel que deixa que o mundo, ou a súa porción del, elixa o seu plan de vida non ten necesidade ningunha doutra facultade máis que a da mera imitación simiesca. Quen elixe o seu plan de vida por si mesmo emprega todas as súas facultades. Debe utilizar a observación para ver, o razoamento e mais o xuízo para prever, a actividade para recoller os materiais para a súa decisión, a discriminación para decidir e, cando xa decidiu, a firmeza e mais o autocontrol para manterse na súa deliberada decisión». A idea da plenitude das capacidades nos exercicios da liberdade está aquí articulada como un exercicio desenvolvido das facultades do individuo, algo que, pensa Mill, non se pode realizar nunha 
concepción que pense o individuo como parte submisa do todo social. A defensa, tan vitoriana no seu ir contracorrente, da excentricidade individual como signo - unha defensa que non podemos disociar da crítica sospeita ao seu elitismomarca unha especie de figura de perfección individual do pleno desenvolvemento de cada un -case un anticipo de si mesmo como unha obra de arte- que en ningún caso, e iso é o importante, pode ser substituída ou suplida polas formas sociais e políticas do costume, ou por calquera idea ou valor que, desde supostos perfeccionistas, queira impor como privilexiadamente mellor unha forma de vida ou unha maneira de desenvolver a propia vida, aínda que esta, precisamente, teña que desenvolverse sobre a base dun perfeccionismo persoal. Boa parte -e talvez a máis interesante- da argumentación de Mill vai encamiñada a examinar as razóns erradas de calquera forma de perfeccionismo social. É interesante, para algo que diremos cando fagamos un bosquexo do terceiro tipo ideal do pluralismo epistémico, que os argumentos de Mill vinculan os criterios de valor, aqueles que empregamos nos nosos exercicios de liberdade, ás diferentes posicións na armazón social, algo que desenvolve nunha máis afinada conceptualización aquilo que mencionaba Humboldt ao referir a diversidade de circunstancias en que se desenvolve cada individuo. Tamén é algo diferente a formulación do principio que debería rexer os límites do exercicio da liberdade individual. O chamado principio do dano que se formula ao comezo de Sobre a liberdade articula o indicado concepto de liberdade coas únicas formas lexítimas da súa restrición. «Ese principio é que o único obxectivo polo que a humanidade está xustificada para interferir, individual ou colectivamente, na liberdade de acción de calquera dos seus membros é a autoprotección. Que o único propósito polo que o poder pode ser correctamente exercitado sobre calquera membro dunha comunidade civilizada, contra a súa vontade, é previr o dano sobre outros» (Mill, 1980, p. 68). Indico que é algo distinta a formulación porque, daquela, a definición social de danar non queda legada a un principio metasocial, senón á argumentación publicamente desenvolvida e xurisprudencialmente articulada do que definamos, precisamente, como dano.

Parei nestas formulacións primeiras da ontoloxía política do liberalismo, que chamei orgánico, porque nelas queda clara a intuición do orixinal e orixinario desenvolvemento das capacidades do individuo; un desenvolvemento que se realiza pola súa propia natureza racional e desiderativa, coma o criterio norma- 
tivo último. Cando nós lemos agora eses textos, non podemos eliminar as sospeitas que elevaron contra ese liberalismo o pensamento de Marx, o socialismo posterior ou outras cuestións sobre o carácter elitista das súas formulacións. Para a indagación conceptual que querería desenvolver, esas sospeitas poden, polo de agora, ser tanto sostidas como deixadas de lado. Porque o que me interesaría suxerir agora é que hai algo do pluralismo orgánico -e aquí o adxectivo empeza a perder o seu sentido- aínda vixente mesmo en formulacións que dificilmente poden sentirse cómodas ao ser adxectivadas de liberais. Refírome, en concreto, á proposta de Amartya Sen de poñer no foco de atención para a reflexión sobre o desenvolvemento social e a xustiza distributiva nas sociedades contemporáneas a idea de capabilities, a das capacidades e habilidades. A idea de Sen é, fronte ás formas do benestar económico, que o desenvolvemento ha de ser pensado coma un proceso de expansión das liberdades reais das que gozan ou poden gozar - en termos normativos, que deberan gozar- as persoas. Estas liberdades reais son aquelas ás que a noción de capacidades lles dá nome, pois as capacidades son a liberdade para alcanzar formas de ser e de facer que as persoas consideran valiosas, aquelas que Sen denomina functionings, funcionamentos. $\mathrm{O}$ desenvolvemento non ha de medirse, daquela, por obxectos ou por magnitudes agregadas -como a renda per capita, por exemplo-, senón pola posibilidade efectiva do exercicio das liberdades que lles permiten aos individuos realizar os seus propios obxectivos. Malia o marco aristotélico en que Sen entende eses funcionamentos ou obxectivos da vida humana, retén unha apelación cara a unha dimensión obxectiva do desenvolvemento das persoas que semella próxima ás reflexións de Humboldt e de Mill que acabo de esbozar. Tan significativas son, neste sentido, as diferenzas que separan as reflexións primeiras e contemporáneas sobre a liberdade como capacidade de desenvolvemento -aquelas cunha noción do Estado abstencionista, estas cunha noción moi diversa do espazo político como protector e facilitador- coma as súas similitudes. Pois a intuición que antes indiquei, a dese desenvolvemento do individuo como criterio normativo último, mantense. As diferenzas, certamente, foron modulándose desde unha confianza, digamos que kantiana, na natureza humana e no seu desenvolvemento, pasando polo laico exercicio dunha individualidade que debe ser protexida, ata un compromiso social que ten en conta a fraxilidade do exercicio desa liberdade. Non en van, a reflexión de Sen parte do interese teórico e 
político de reflexionar sobre a pobreza e sobre os criterios normativos que cómpre utilizar na xustiza distributiva.

A confianza no desenvolvemento do individuo e o valor absoluto da súa liberdade para facelo eran, no primeiro liberalismo, razón suficiente para formular unha teoría abstencionista -e, cabe dicir, residual, do público. Na medida en que ese desenvolvemento, que segue a ser o criterio normativo, se vexa ameazado, imposibilitado pola natureza e pola sociedade, o público pode adoptar formas protectoras e reparadoras que palíen as continxencias derivadas das posicións sociais dos individuos. Pero iso semella xa abrir a porta para considerar a segunda forma de pluralismo, a que denominei o pluralismo da imposibilidade de que persoas sexan substituídas. Antes diso, non obstante, paga a pena retornar por un momento ao punto de partida. As formas do comunitarismo de Estado, que fai imposible ver o pluralismo, non teñen por que oporse ás proteccións e coidados das continxencias das persoas. Pero, certamente, non realizarán esas accións paliativas polo valor que lle asignen á liberdade dos individuos para levar a cabo as súas capacidades. Farano, por exemplo, porque as continxencias impiden a súa funcionalidade social ou porque reducen o exercicio de valores definidos de xeito perfeccionista. A protección asistencial é conceptualmente diferente e institucionalmente distinta, penso, da xustiza distributiva que vén requirida pola protección da capacidade de acción dos individuos.

\section{A ONTOLOXÍA POLÍTICA DOS INTERPELANTES E OS INSUBSTITUÍBLES}

A idea de fraxilidade e de continxencia que introducín nas últimas versións do pluralismo orgánico pode dar paso á segunda forma de ontoloxía política da diversidade que quero presentar. Esa mesma idea de fraxilidade, ou de pobreza, é absolutamente contemporánea e cabe pensar que as experiencias traumáticas do século XX fixeron insostible a anterior confianza nas ordes cegas ou nos plans ocultos daquelas forzas -quer a natureza, quer o mercado- que se pensaba que regulaban a vida social. As reflexións de Arendt, Levinas e Habermas, que -de maneira arriscada filosoficamente- vou tomar como exemplo dunha ontoloxía política distinta á que acabo de expor, levan sen dúbida a marca deses traumas 
e talvez non sexa desacertado suxerir que iso induce un cambio da perspectiva metodolóxica na concepción do pluralismo e na súa ontoloxía. Se as propostas do pluralismo orgánico semellan pensarse, en actitude obxectiva de terceira persoa, como definicións - ben filosóficas, ben das Ciencias Sociais- do que fai diversas e irredutibles as persoas, definicións que adquiren un carácter normativo ao definir os marcos lexítimos da relación entre os cidadáns e o Estado, os deste segundo tipo de pluralismo semellan, pola contra, pensar os individuos como axentes ou como actores, como performativamente participantes, nas súas interaccións regradas normativamente -quer en termos éticos, quer en termos políticos. A intuición específica deste tipo de pluralismo é que esa participación activa se pensa, precis amente, como a actividade ou a presenza de individuos que non poden ser substituídos ou equiparados antes da interacción en que se atopan. A idea de Arendt da diferenza das persoas e da política como aquilo que entre eles acontece, a reflexión de Levinas sobre a responsabilidade que non se resolve ou non se acomoda ao preestablecido en normas sociais e a formulación de Habermas dos discursos prácticos de xustificación de normas como indisolublemente ligados á lexitimidade que só lles pode prestar a participación dos implicados en tales normas coinciden nese punto común dunha irredutible diferenza que ten alcance normativo. Certamente, e polo obvio que é, non resulta merecente dunha atención detallada agora -aínda que precisaría doutras moitas consideracións-, esas reflexións obedecen a linguaxes filosóficas e a intereses que son moi diferentes polas súas tradicións e os seus obxectivos. Paga a pena indicar, cando menos, unha. Mentres Arendt e Habermas acentuarán, novamente malia as súas importantes diferenzas, a forza comunicativa das interaccións que deberán trasladarse, en diversas maneiras, á definición da esfera política, Levinas, polo menos na interpretación que diso fixo Derrida - por exemplo, na súa reflexión sobre o perdón-, e por medio do que se veu en chamar o dobre vínculo -o ético e mais o político- mantén unha tensa segregación entre o discurso da responsabilidade moral e as tarefas políticas. Para Levinas, a orde ética e política non se atopan, aínda que se crucen no encontro necesario do outro. Malia, novamente, esas diferenzas, o vínculo normativo da ética e da política está baseado, nos devanditos autores, nunha similar intuición da particularidade insubstituíble de cada un na interacción cos demais. Difiren, e iso é importante, na maneira en que esa particularidade se vincula co normativo -moral, político. No caso de Habermas 
e mais de Arendt, na tamén distinta conformación comunicativa do espazo público; no de Levinas (1998, p. 157), na aparición da figura dun terceiro que, como o outro xeneralizado de Mead, sempre aparece na particularidade de cada encontro con cada outro concreto. Que iso xere, en Levinas, o paradoxo de que a política tanto é a orixe como a cura da pobreza do outro, talvez non estea lonxe dos fracasos da acción política que analizou Arendt e mesmo dos outros fracasos da acción comunicativa que Habermas examinou respecto das formas de constitución do público nas sociedades contemporáneas.

Aínda que force, pois, as intuicións, a suxestión de Levinas (1996, p. 169), segundo a que «nada sería capaz de liberarse do control da responsabilidade do "un polo outro" que delimita o límite do Estado e que non deixa de apelar á atención das persoas, que non podería ser satisfeita coa mera submisión de casos baixo unha regra xeral, que podería facer el só un ordenador», semella apuntar tamén a unha idea común que, cambiadas as linguaxes, poderían compartir Arendt ou Habermas. Porque o pluralismo do insubstituíble quere presentarse en oposición ás formas técnicas, laborais ou sistémicas da organización social -coas que se materializou e coas que se pensou o que antes denominabamos a unión social. A matizada desconfianza de Arendt ou de Levinas - de orixes tamén distintas- fronte ás formas políticas liberais ten a mesma raíz xa que se pensa sempre a forza, a enerxía do encontro ou da interpelación como orixinariamente diferente á herdada potencia das formas políticas. Habermas, sen perder, non obstante, o seu talante crítico fronte ás formas liberais políticas contemporáneas, acentuaría máis a continuidade entre aquela forza e as institucións necesarias das sociedades complexas. Pero, malia iso, a atención ás persoas das que fala a cita de Levinas volve poñer no medio a intuición desta forma de ontoloxía do pluralismo que indica que son os individuos as únicas fontes de autoridade desde as que pensar a validez da orde social e que o son, ademais, como axentes que interpelan e son interpelados por outros ao formular, nos seus xuízos e nas súas accións, aquilo que entenden que son as consecuencias da súa responsabilidade.

Levinas entende con frecuencia a democracia coma unha irrupción ética na política (Herzog, 2002, p. 215). Sen necesidade de adoptar o seu frecuente e ás veces inquietante ton mesiánico, si cabe pensar nunha idea de poder constituínte, ou instituínte, por empregar a palabra de Claude Lefort, como efecto político desa irrupción. Arendt, cos seus estudos sobre a revolución e coa súa 
concepción da acción e Habermas coa súa «modelización» da democracia deliberativa poderían coincidir con ese acento que non é negado, aínda que sexa complementado, cando o autor de Facticidade e validez insiste en que ese carácter instituínte ha de realizarse, cando do público e político falamos, na linguaxe normativa do Dereito. Fronte a aquel carácter abstencionista do primeiro liberalismo, e a diferenza do carácter protector ou reparador do Estado de benestar que só fugazmente fixo a súa aparición nalgunhas nacións occidentais, uns caracteres que eran congruentes coas diversas formas do pluralismo orgánico, o pluralismo da interpelación ou da insubstituibilidade de cada un apunta a unha concepción do espazo público como resultado de accións e interaccións, como algo que pode ser fundado novamente e, ás veces, como acontece en Arendt, que pode ser radicalmente alterado nas revolucións. $\mathrm{O}$ feito de que, no caso de Habermas, esa nova fundación, como nova significación de sentidos e como novo deseño das institucións, deba acomodarse a acordos normativos -como tamén acontece en Levinas- non nega, como dixen, este trazo diferencial.

Pero a pregunta que cómpre, daquela, formular é aquela que se refire ás formas, aos procedementos e ás razóns desa capacidade instituínte do "nós» que constitúe o público. Permítaseme, para concluír este apartado sobre o pluralismo ontolóxico da interpelación, unha breve reflexión sobre o carácter deste «nós». A aspiración moral, xurídica e política a vivir nunha sociedade xusta, sen mal, leva consigo a intuición dunha unión social que pensamos como unha unidade de axencia e de criterios ou de procedementos, que aplicase, precisamente, as formas materiais e concretas que reviste aquela aspiración a vivir nunha sociedade xusta. Pensamos o «nós»-o nós colectivo, o nós de «Nós, o pobo»- coma unha forma de unidade, coma un ser ou coma un espazo, ao que lle correspondería a tarefa da xustiza; porque ese nós é o suxeito da xustiza. Pero a historia das formas políticas e da filosofía política mostra que temos intuicións moi contraditorias, e decote moi borrosas, sobre que é ou quen é ese suxeito; e seguimos a ter acotío intuicións imposibles respecto del. En primeiro lugar, porque a axencia colectiva é máis unha metáfora coa que nomeamos un sistema de institucións - por exemplo, os poderes lexislativo, xudicial e executivo- e un sistema plural de axencias -a sociedade civil xunto á sociedade política, o Estadocuxa unidade de acción é conflitiva e decote descompasada. As nosas intuicións sobre a unidade de axencia e sobre a unión social difráctanse no coñecemento 
que temos como cidadáns das lóxicas reais, non sempre confluentes das axencias reais -económicas, sociais, políticas- que, de feito, fan o tecido -acotío descosido- das nosas vidas sociais e dos espazos en que estas se desenvolven. En segundo lugar, e mesmo aceptando a pouca claridade das nosas intuicións sobre a unión social ou a súa complexidade -por exemplo, coa noción, socioloxicamente descritiva e normativamente estruturada-, porque eses particulares «nós» -os «nós» de cada pobo que asine, cando o faga, a súa carta fundacional nunha Constitución- semellan, de feito, impotentes como axentes efectivos. Moitas das decisións, case todas as importantes, non lles competen xa aos Estados e moitos dos grandes problemas, os que seguen sen solución, desde a desigualdade e a pobreza ata a posibilidade de soster a vida no planeta Terra, semellarían requirir unha forma de axencia colectiva, da especie, da que só temos, por unha banda, unha intuición moral insuficiente e moitas dispersas, non sempre congruentes, e ineficaces axencias parciais, pola outra.

Estas desesperacións que habitamos na nosa condición de cidadáns nas nosas quebradas metrópoles e na nosa fracturada cosmópole só poderán disolverse na acción política e non é a misión, ao meu ver, da filosofía ao substituír esa acción. Pero si pode selo ao intentar dar conta de que elementos haberían de entrar nela como as súas condicións necesarias, aínda que só sexa para que os cidadáns entendamos que facemos cando o facemos ou cando o fagamos. No que levamos visto, o pluralismo orgánico acentuaba a liberdade de axencia como un de tales elementos e o pluralismo da interpelación o carácter de atención á particularidade de cada un que configuraba a forza constituínte do público. O terceiro tipo de ontoloxía do pluralismo subministraranos outra intuición, ao meu ver complementaria e que ten relación coa forma das razóns que nos damos ou nos poidamos dar, como explicacións e como xustificacións, no proceso das nosas accións para instituír o público.

\section{A ONTOLOXÍA POLÍTICA DAS DIFERENZAS EPISTÉMICAS}

Xa dixen antes que as diferenzas das posicións sociais, das circunstancias, facían posible unha concepción dun pluralismo que non permitía substituír os individuos - no caso de ontoloxías individualistas- na tarefa de definir os seus plans 
de vida; unha incapacidade para substituír que, como despois vimos, os fai a todos imprescindibles na constitución do espazo público. Aquelas diferenzas de posicións sociais terían que determinar, daquela, as maneiras en que os individuos conciben as súas accións e o público mesmo. A diversidade de continxencias e de posicións lévanos á idea dunha forma de pluralismo, o pluralismo das razóns, e das razóns razoables, que estarán presentes necesariamente nas nosas comprensións do público. Como indiquei ao comezo, podemos tomar a John Rawls como modelo para este terceiro tipo de pluralismo.

É a conciencia deste pluralismo, que non pode ser erradicado se non é por medio da violencia pública, o que levou a Rawls á formulación modificada da súa teoría da xustiza en $O$ liberalismo político. Interésame destacar a súa reflexión sobre o que el denomina «as cargas do xuízo» (1993, p. 54-58). Rawls pregunta como é posible dar conta da diversidade de doutrinas comprehensivas razoables. Notemos que non se trata de que exista o pluralismo de opinións ou de doutrinas, un feito socialmente obvio, senón máis ben de como explicar que mesmo posicións perfectamente racionais, coherentemente articuladas e que tratan por igual de dar conta do mundo social, poidan ser diferentes e incluso discrepar nas súas interpretacións e as súas razóns. Esta forma de pluralismo, o pluralismo do razoable, leva consigo a consecuencia de que calquera doutrina ten que recoñecer e asumir que os seus xuízos están lastrados, por así dicilo, posicionalmente. Por que non sucede na vida social o que, supoñemos, ha de acontecer na ciencia, é dicir, a confluencia de doutrinas e o acordo sobre unha verdade non discutible? Rawls tenta solucionar este problema -tanto social como filosófico- acudindo ao carácter epistemicamente borroso das nosas crenzas empíricas e morais ou políticas, ao diferente peso que lles podemos asignar nas nosas ponderacións das circunstancias, ás diferenzas na valoración e relevancia que lles asignemos a esas diversas consideracións, á capacidade restritiva que teñen os sistemas sociais para integrar valores diversos e á necesidade que teñen as institucións de seleccionar aqueles que, entre eles, pense que son relevantes. Rawls (1993, p. 57) indica que "todo sistema ou institución ten, por así dicilo, un espazo social limitado. Ao verse na obriga de seleccionar algúns dos valores que se subscriben, ou cando sostemos varios deles e debemos restrinxir un punto de vista debido aos requisitos impostos por outros, enfrontámonos a grandes dificultades para seleccionar as nosas prioridades e para 
facer axustes entre elas». A conclusión á que chega Rawls (1993, p. 58) é que «moitos dos nosos xuízos máis importantes se realizan en condicións en virtude das que non se pode agardar que persoas cabalmente conscientes, con plenos poderes racionais, cheguen ás mesmas conclusións, mesmo despois dunha libre discusión».

O especialmente relevante, ao meu ver, para o que pretendo neste traballo, é que o tipo de pluralismo que impoñen as cargas do xuízo está encamiñado a mostrar a inviabilidade de calquera doutrina perfeccionista que, en actitude de terceira persoa, fixe a verdade das crenzas morais e políticas, estableza prioridades e determine a forma das accións. Boa parte da argumentación de Rawls faise eco das de Humboldt e Mill, e, en concreto, esta oposición á tiranía posible e real da imposición dun único punto de vista sobre os participantes. Para a posición da ontoloxía do pluralismo epistémico, a orde social -a unión social, por empregar o termo humboldtiano ao que o propio Rawls recorre- establécese como un sistema de institucións e de normas cuxo acordo ten que operar sobre o poder moral do razoable. O razoable non anula o pluralismo, senón que é o exercicio da razón logo de constatar que non pode ser erradicado agás pola violencia. As institucións da democracia non son, daquela -no nivel de teoría no que nos movemos-, o froito da violencia, senón exactamente o seu oposto. Non é preciso entrar agora no detalle da proposta do liberalismo político rawlsiano, pero paga a pena sinalar que a racionalidade é o exercicio práctico da razón en condicións de continxencia e de diferentes posicións sociais e que, fóra da forma que adopte na proposta rawlsiana, semella tamén un trazo necesario naquelas comprensións que, como cidadáns, nos vemos movidos a facer para realizar as accións políticas que as nosas inxustas sociedades reclaman.

Nesta proposta aparecen diversos problemas. Un deles, que deixarei agora de lado, é o de como é posible, daquela, acordar razoablemente prioridades, razóns e obxectivos nas accións colectivas. A resposta rawlsiana, a do consenso por superposición ou por solapamento de doutrinas ou de razóns, é coñecida. Pero, nos termos en que se formulou o problema das cargas do xuízo, cabe pensar que os criterios que empregarán os diversos individuos ben terán que diferir sempre ou ben deberán coincidir, por algunha razón non explicada, naqueles casos en que se producen acordos de crenzas e acordos en prioridades e en accións. Un segundo problema, co que a teoría rawlsiana se enfronta dunha maneira sis- 
temática e que está relacionado co que acabo de mencionar, é se o acordo pola coincidencia parcial das, inevitablemente, plurais doutrinas non será máis ben o resultado de acomodos, historicamente continxentes e afortunados. A sospeita de que o resultado sexa o dun modus vivendi insatisfactorio, coma unha proposta normativa xusta, pode ser ampliada, alén do que Rawls analiza, se pensamos que os criterios racionais están cultural, civilizada ou posicionalmente determinados e que os marcos locais en que explicitamente se formula semellan requirir un ulterior grao de abstracción para afrontar unha perspectiva cosmopolita. $\mathrm{O}$ risco de que a proposta sexa só a dun modus vivendi faise máis grave e máis patente no ámbito que Rawls denominou «a lei dos pobos».

\section{AS LECCIÓNS DO PLURALISMO}

Fun sinalando, en cada unha das ontoloxías políticas que esbocei, algúns dos problemas que os atinxen. No caso do pluralismo orgánico do protoliberalismo, indiquei un trazo elitista que radica na forma en que o seu individualismo é elevado a criterio normativo; ademais, iso pode provocar, ás veces paradoxalmente, un paternalismo perfeccionista na comprensión individualista do propio proxecto e unha concepción abstencionista do público. No segundo caso do pluralismo da interpelación, suxerín o problema co que se enfronta verbo da comprensión da dimensión normativa, instituída, das interaccións. No terceiro suposto indiquei o risco de que o pluralismo epistémico acabe por toparse, á hora de xustificar normas e institucións, con formular só un modus vivendi. Estes problemas e riscos son, en diversas maneiras, abordados nas distintas teorías ás que fixen referencia. Non obstante, e malia as formas máis ou menos satisfactorias coas que logran acomodar respostas a eles -é o momento de lembrar que os distintos autores recorren, alén das idealizacións por medio das que presentamos as súas respectivas doutrinas, a elementos das outras-, cabe pensar que eses riscos e problemas teñen a súa raíz na concepción estrutural de cada un dos pluralismos que analicei. $\mathrm{O}$ primeiro pluralismo orgánico concibe os criterios normativos en termos só individualistas e ten que comprender o público só de maneira residual: é só cada individuo o que decide sobre si mesmo. O segundo pluralismo, aínda que pensa «heterocentradamente» eses criterios, ten problemas para 
acomodar a dimensión normativa instituída, que pode acabar só como un compoñente instrumental das interaccións humanas. $\mathrm{O}$ terceiro pluralismo epistémico semella ter que acoutar culturalmente os seus criterios de validez dado o carácter parcial dos seus acordos sobre os espazos públicos, nacionais, aos que se refire. Estes problemas estruturais aparecen tamén con nitidez cando vemos as concrecións históricas, ideolóxicas, nas que teñen que tomar corpo algunhas versións, reducionistas, deles. O liberalismo socialmente desinteresado, a concepción só instituínte das interaccións sociais e a concepción adánica que parece traer consigo aos procesos sociais, e as formas imperialistas de concepción da axencia global son formas que cabe denominar patolóxicas dos nosos imaxinarios políticos.

De diversas maneiras, e esta é a discusión contemporánea, podemos abordar eses problemas no seo de cada un dos modelos que expuxen e esa é unha parte central dos nosos traballos teóricos. Querería concluír cunha suxestión de orde metateórica -e que máis é un proxecto- que talvez axude a eses traballos. Aínda que fun ganduxando o distinto tratamento dos diversos pluralismos, quizais conveña velos como aspectos da nosa comprensión das nosas accións regradas, como expresión dos puntos de vista que adoptamos fronte a esas accións, como tipos que precisan ser integrados para evitar os riscos estruturais en que cada un deles, por separado, pode incorrer. O tipo de pluralismo orgánico adopta unha perspectiva en terceira persoa que parece non atender á perspectiva, en segunda persoa, que acentuaba o pluralismo da interpelación. Este, pola súa vez, semella descoñecer a forza que o terceiro acentúa ao indicar que a perspectiva da primeira persoa do plural, o «nós», é unha condición necesaria para entender a orde normativa. Pero, así mesmo, o terceiro tipo de pluralismo epistémico semella carecer, nas novas condicións de globalización, de criterios obxectivos como os que subministraba a primeira perspectiva en terceira persoa ${ }^{2}$. Concibir o inevitable e desexable pluralismo nas nosas condicións semella requirir, daquela, unha concepción del que non reduza a súa comprensión a unha soa das devanditas perspectivas. Precisamos, se temos que atender ao desacougo cidadán diante dos problemas aos que cómpre facerlles fronte, conxuntar as intuicións

\footnotetext{
2 Esta suxestión está inspirada na conxectura coa que Rawls (2000, p. 183) interpreta as diversas formas do imperativo categórico kantiano.
} 
dos tres tipos ideais de pluralismo que recorrín. Necesitamos non só acentuar, como direi no seu momento, o papel insubstituíble das persoas, senón tamén os criterios obxectivos e normativos que lle permitan a cada un chegar a formular o seu propio destino. Precisamos tamén entender que estes criterios só poden operar no marco dunha perspectiva activa, performativa, que ten dimensión colectiva. Necesitamos, por último, comprender que esa acción reclama atender a plural conformación real da condición humana. Penso que aínda carecemos dunha comprensión teórica -e non digamos xa política- que nos permita integrar esas necesidades, e chegar a ela é unha tarefa non só necesaria senón tamén apaixonante. 


\section{BibliografíA}

Herzog, A.: «Is Liberalism "All We Need”?: Lévinas's Politics of Surplus», Political Theory, vol. 30, n. ${ }^{\circ} 2$ (2002).

Humboldt, W. von: The limits of State Action, Indianapolis, 1993.

LeVINAS, E.: Basic Philosophical Writings, Indiana Univ. Press, 1996.

Levinas, E.: Otherwise than Being, Duquesne Univ. Press, 1998.

Mill, J. S.: On Liberty, Londres, Penguin Classics, 1980.

RaWLS, J.: Political Liberalism, Nova York, Columbia University Press, 1993.

RAWLS, J.: Lectures on the History of Moral Philosophy, Harvard Univ. Press, 2000. 